\title{
Under the Banner Dakwah: the Radical Potential among Muslim Students in Riau
}

\section{Munzir Hitami}

Universitas Islam Negeri (UIN) Sultan Syarif Kasim Riau, Indonesia mzr.hitami@gmail.com

\author{
Abu Bakar \\ Universitas Islam Negeri (UIN) Sultan Syarif Kasim Riau, Indonesia \\ abubakarms@uin-suska.ac.id

\section{Imron Rosidi} \\ Universitas Islam Negeri (UIN) Sultan Syarif Kasim Riau, Indonesia \\ imronrosidi@gmail.com

\section{Imam Hanafi} \\ Universitas Islam Negeri (UIN) Sultan Syarif Kasim Riau, Indonesia \\ imam.hanafi@uin-suska.ac.id
}

\section{Abstract}

This study is based on the presence of spirit (ghirah) to return to Islamic teachings among Muslim students in Riau after the 212. This study shows that: First, the ulama who has the same understanding with students is Habib Rizieq Shihab. Second, the idea about Khilafah Islamiyah and the implementation of syari'ah or Islamis law is still dominant. Third, there is an idea that killing is a part of jihad. Fourth, the consciousness about differences is still low. Based on this finding, the radical potential which is high among students is basically disquieting. Furthermore, the basis of this understanding is affected by the dakwah concept of some extra campus organizations and their ideological organization.

Keyword: Radicalism, Muslim Studies, Riau. 


\section{Abstrak}

DI BAWAH PANJI DAKWAH: POTENSI RADIKALISME PADA MAHASISWA MUSLIM DI RIAU. Kajian ini didasarkan pada gejala munculnya semangat (ghirah) untuk kembali kepada ajaran Islam di kalangan mahasiswa Muslim di Riau pasca 212. Hasil kajian ini menunjukkan bahwa: Pertama, figur ulama yang memiliki pemahamaan dengan mahasiswa adalah Habib Rizieq Shihab. Kedua, ide tentang perlunya Khilafah Islamiyah dan penerapan syari'ah Islam masih mendominasi. Ketiga, masih terdapat pandangan bahwa membunuh sebagai bagian dari makna jihad. Keempat, kesadaran akan adanya perbedaan masih rendah. Berangkat dari hasil tersebut, potensi radikalisme yang menggejala di tengah-tengah mahasiswa tentu cukup menghawatirkan. Lebih-lebih basis pemahaman itu dipengaruhi oleh konsep dakwah beberapa organisasi ekstra kampus dan pandangan ideologis organisasi.

Kata Kunci: Radikalisme, Mahasiswa Muslim, Riau.

\section{A. Introduction}

Normatively, religion and radicalism may nothave relationship at all. However, empirically, there is a correlation which cannot be neglected. This can be seen from the radical actions in the name of religion. According to Wilkinson from The Terorism Research Center CSIS (1995), radicalism comes from Islamic fundamental groups existing in Islamic states. ${ }^{1}$ It should be acknowledged that radicalism like suicide bombing is extraordinary action so that the motive to conduct this is also based on the extraordinary reason, at least a strong rooted ideology. The strong and rooted ideology behind the actors of suicide bombing plays a crucial role for them in creating and doing radicalism.

Witdarmono, in his article published on Kompas titled "Teror dalam 'Benak' Agama: Wacana Agama dalam Radikalisme” states:

"Radikalisme juga tidak lepas dari munculnya paham fundamentalisme agama. Secara historis istilah fundamentalisme

${ }^{1}$ Witdarmono, "Teror dalam 'Benak' Agama: Wacana Agama dalam Radikalisme", Kompas, December 30, 2002. 
awalnya dikenal di kalangan Kristen, istilah tersebut merupakan sebuah sistem religius dan intelektual yang bertumpu pada inerrancy dan infallibility dalam memahami alkitab. Sedangkan di dalam Islam, fundamentalisme pertama-tama lebih bersifat gerakan social yang mengambil bentuk keagamaan. Umumnya, fundamentalisme Islam merujuk pada empat hal: Pertama, pembaharuan. Kedua, reaksi pada kaum modernis. Ketiga, reaksi pada westernisasi. Keempat, keyakinan terhadap Islam sebagai ideology alternative."

(Radicalism cannot be separated from religious fundamentalism. Historically, it comes from Christianity. It is intellectual and religious system based on inerrancy and infallibility in understanding the bible. In Islam, it is firstly in the social actions forming into religion. Generally Islamic fundamentalism refers to four elements: the first is renewal, the second is reaction to modernist group, the third is reaction to westernization, the fourth is a belief to Islam as the alternative ideology.)

The above view confirms that the root of radicalism is religious fundamentalism. There are simply two main variables to be understood the relation and the rise of fundamentalism and radicalism in a Muslim society. The first is internal factor and the second is external factor. The first is explained by Muhamad, ${ }^{3}$ stating that radicalism comes from Muslims who want to establish an Islamic State and to gain this goal they use violent ways. This violent ways to implement the Islamic law are considered as jihad. ${ }^{4}$ The jihad is understood by some Muslims based on the literal paradigm. Literalism is identical with extreme understanding. ${ }^{5}$ They

\footnotetext{
${ }^{2}$ Witdarmono.

${ }^{3}$ Ali Muhammad, Agama dan Konflik Sosial (Bandung: Marja, 2013), 63.

"Jihad" is their slogan. The use of "jihad" is a proof that they try to legitimize their action as the religious practices so that their action can be categorized as a fight.

${ }^{5}$ Furthermore, there are six mode of literalist. First, believe that the logos of knowledge is not equal to understand the world. Second, increasing the religious myths. Third, presenting the charismatic religious figure as the representation of the prophet of Muhammad as ideal type. Fourth, presenting the high obligation on holy things. Fifth, forbidding the critical questions and tending to make the profane life aspects sacral. Sixth, presenting the eschatology life as the real life. Yudhie Haryono, Melawan dengan Teks (Yogyakarta: Resist Book, 2005), 80. This radical understanding cuts the text and context (both characteristically history and reading time). Finally, Islam is no longer communicative with the context of its adherents.
} 
understand religious texts as the closed corpus, they understand the truth as they have. As a result, they do not acknowledge other people's understanding except their own understanding. ${ }^{6}$

The implication is that they always view the world from the binner opposition, namely dar al-harb (non-Muslim state) and dar al-Islam (Islamic state). Areas regarded as dar al-harbi are viewed as the object of expansion and war. In this case, jihad is used as a mobilization slogan presenting "frightening" Islam. ${ }^{7}$

Some studies show that the rise of radicalism is supported by extreme fundamentalism and religious radicalism among people. ${ }^{8}$ Furthermore, Bakti says that radicalism is affected by some factors: exclusive and legalistic understanding, "bad" appreciation to minority group, lonely feeling from collective life (Muslims are always discriminated) and the presence of radical organizations. ${ }^{9}$

In other words, the rise of radicalism is supported by the external factor. In this case, radicalism emerges from the reaction to modernization promoted by the West in Muslim world. The presence of modernization with its impact is being understood as a threat to the traditional authority. Furthermore, the ideology of "modernism, liberalism, and humanism" is viewed as the failed ideology to give a solution so that radicalism becomes dominant in the Muslim world. ${ }^{10}$

The presence of religion in the human life has been perceived diversely. As the meaning system, it has two main functions in individual and social life, namely regulation and justification. It is as

${ }^{6}$ Some of Muslim thinkers mention that the model of thought often refers to Wahhabis tending to be radicalism. For instance in $1159 \mathrm{H} / 1746 \mathrm{M}$, the Wahhabis proclaimed the formal Jihad to fight all people who do not have the same ideology as their ideology. They are regarded as the infidels. Hamid Algar, Wahabisme: Sebuah Tinjauan Kritis (Jakarta: Paramadina, 2008), 53; A. Shihabuddin, Membongkar Kejumudan (Bandung: Mizan, 2013), 2-6.

${ }^{7}$ Muhammad Asfar (ed.), Islam Lunak Islam Radikal: Pesantren, Terorisme, dan Bom Bali (Surabaya: JP Pres, 2003), 67.

${ }^{8}$ For example a study done by A.S. Bakti, “Terorisme dan Tantangan Radikalisme Baru dalam Sistem Kepemimpinan Nasional", Jurnal Politik dan Keamanan Nasional 5, No. 1 (2015), 9.

${ }^{9}$ Bakti.

${ }^{10}$ Muhammad Asfar (ed.), Islam Lunak Islam Radikal, 67. 
regulation which means as the patron of value. Therefore, religion is put as a guidance of human life. It becomes the spiritualistic or materialistic reference. Religion as justification means that it functions as moral foundation for action. ${ }^{11}$

This indicates that religion is the basis of value which is fundamental and universal so what is the correlation between religion and radicalism? Based on the above explanation, there are at least two possible correlations between religion and fundamentalism. First, religion has become the source of radicalism when it is implementation of religious order, ${ }^{12}$ both directly and indirectly. ${ }^{13}$ This is commonly caused by textual understanding. Second, the correlation between religion and radicalism is coincidental. Religion is not as the factor but it is used for moral reasoning to conduct such action. ${ }^{14}$ In this case, religion has become the foundation and reasoning for the actor's interest. This is a logical consequence of religion as universal value.

This distortive understanding can frame the young generation thought in Indonesia. This can be seen from the J.W. Marriott bombing in which the actor of suicide bombing is Dani Dwi Permana who is still young. By using the jihad banner (jihad fi sabilillah), they intend to use youth and students to implement their agenda. ${ }^{15}$

Munip's study indicates this. ${ }^{16}$ According to him, an effort of disseminating the radical ideology is done through the Rohis (Islamic organization in school) in Sekolah Menengah Pertama (SMP, Junior High School) and Sekolah Menengah Atas (SMA, Senior

${ }^{11} \mathrm{~J} . \mathrm{H}$. Lauba, Psychological Study of Religion (New York: MacMillan, 1912), 5.

${ }^{12}$ In such context, religion is put as the reason to support their actions, "amar ma'ruf nahi munkar" refers to the prophet statement: those who see the bad things, change them with your hand. If you are unable to use it, change with your mouth. If you are still unable to use your mouth, please change with your hearth. But, this is the most weaknesses of the faith (hadith by Muslim). This hadith has been used the universal reference for the radical groups. Their actions then are categorized as the manifestation of religious teachings to reach the best community "khairu al-ummah" in this world.

${ }^{13}$ Adjie S., Terorisme (Jakarta: Surya Multi Grafika, 2005), 146.

${ }^{14}$ Adjie S.

${ }^{15}$ Adjie S., 90.

${ }^{16}$ Abdul Munip, "Mencegah Radikalisme Agama di Sekolah", Jurnal Pendidikan Islam 1, No. 2 (2012), 167. 
High School). In which its members are youth. A survey done by the Lembaga Kajian Islam dan Perdamaian (LaKIP, Institute of Islamic Studies and peace) Jakarta shows that 48,9\% students in the Jabodetabek (Jakarta and its surrounding areas) agree to radical and violent actions. ${ }^{17}$ In the early 2011, 3 students coming from 1 school in Klaten, ${ }^{18}$ are involved in the radical actions. This is an indication that radicalism has entered to schools and targeted young Muslims who are still students.

According to Darmawati $\mathrm{H}$. and Abdullah Thalib, young generations, especially students are susceptible to be penetrated with the radical spirit and understanding based on religion. They are still young with a strong spirit to practice Islamic teaching authentically and comprehensively. This makes them as the most susceptible social group penetrated by radical issues and ideology. ${ }^{19}$

In this case, education institutions should be responsible to the rise of radicalism. As the locus of transfer of knowledge, education plays a crucial role in implementing knowledge which is tolerant and inclusive. The wrong understanding about diversity and multiculturalism contributes to the rise of radicalism. This is because they use the text as the only authority of knowledge. This can bring exclusive understanding among people. The wrong paradigm (binary opposition) always brings someone to the black and white choices.

\footnotetext{
${ }^{17}$ Survey was done from October 2010 to January 2011 in Jabodetabek. This research was done in 100 Junior High Schools and 100 Senior High Schools. This research uses face-toface interview method with questionnaires guidance and the samples are selected randomly. The limit of error sampling is about 3,6\% for teachers of Pendidikan Agama Islam (PAI) and $3,1 \%$ for students. The populations are PAI teachers at Junior and Senior High Schools in Jabodetabek. The total populations of the PAI teachers taken as the samples are 2.639 people consisting of 1.639 PAI teachers at Junior High School and 800 PAI teachers at Senior High Schools. From the populations, the samples consist of 590 teachers, 327 PAI teachers at SMP and 263 PAI teachers at SMP/SMA. The total samples for students are 993 students consisting of 401 SMP students and 592 students at SMP/SMA. Source: www.swatt-online. com/2011/04/lakippemerintah-harus-tinjau kembali-pendidikan-agama-islam/, accessed March 17, 2019.

${ }^{18}$ Andry Prasetyo, "Enam Terduga Teroris dari Satu Sekolah", https://m.tempo. co/ read/news/2011/01/27/063309390/enam-terduga-teroris-klaten-dari-satu-sekolah, accessed March 10, 2017.

${ }^{19}$ Darmawati H. and Abdullah Thalib, "Respon Siswa Madrasah Aliyah Negeri (MAN) terhadap Radikalisme Agama di Makassar”, Jurnal Sulesana 10, No. 1 (2016).
} 
Education as the locus of value transfer also contributes to the exclusive understanding to students. Education is basically is a place of production and reproduction of knowledge. However, in reality, it is mostly used as the imbalanced knowledge and thought transfer. Students are always put as the object of education, not as the subject. As a result, education dehumanizes human beings. ${ }^{20}$

In the learning process at Islamic high schools, for instance, there are some material contents which can direct students to the radical ways. Some of the are: First, the content of the Al-Qur'an dan Hadits in second semester of XII class about Q.S. al-Kafirun [109]: 1-6 invites Muslims to kill or fight to the infidels (kafir). Second, the content of Fiqh first semester of XII class explains about the obligation to implement the khilafah. Third, the content of Fiqh second semester of XII class explains about the obligation for Muslims to choose leaders from the Quraisy. ${ }^{21}$

The above examples can produce intolerant, radical, and exsluisve ideology to students when their teachers do not creatively interpret the content inclusively. ${ }^{22}$ This research then will look at the extent to which the conception and perception of young Muslims in Riau responding the radical ideology. The potential of radicalism is based on three indicators: namely students' response in fighting the khilafah and Islamic law, their response on the

\footnotetext{
${ }^{20}$ This model has made the student to receive one model of thought an sich. In Foucault language, they are in the process of disciplining body. Imam Hanafi, "Foucault dan Pendidikan Kita", Riau Pos, June 7, 2017.

${ }^{21}$ Books of teaching in Islamic Senior High School based on Peraturan Menteri Agama Nomor 2 Tahun 2008.

${ }^{22}$ Imam Hanafi shows that the tendency of learning Islam in schools is fiqh oriented, emphasizing on wrong-true, permitted-forbidden, Muslim-infidels and so forth so that it becomes monolithic and less respect to the spirit of multiculturalism among students. As a result, there is the fiqh paradigm (namely the truth claim, the single mazhab and piety is measured by practicing the fiqh), religious fanatism, discrimination, and religious conflict. Imam Hanafi, "Orientasi Fiqhiyah dalam Pendidikan Islam", Proceding Annual International Conference of Islamic Studies (AICIS) 2014 (Jakarta: Kementerian Agama RI, 2014). See also Abdul Wahid's study concluding that Islamic education: (1) more oriented to cognitive development; (2) focusing on intellectual development by emphasizing on fiqhiyah or syar'iyah; (3) the theology content tends to emphasize on scholastic theology which is exclusive. Abdul Wahid, "Tendensi Antipluralisme dalam Pendidikan Islam: Kritik Teks Buku Ajar PAI SMU/SMK", Ulumuna 12, No. 2 (2003).
} 
differences, and their response on Islam dan syari'ah Islam, and their response on suicide bombings as the jihad.

This research was done generally in three stages, namely orientation, exploration, and interpretation stage. In the orientation, survey is done by spreading questionnaires to respondents. ${ }^{23}$ Questionnaires are made based on the radicalism indicator which becomes the focus of this research. In the exploration and interpretation stage, the Focused Group Discussion (FGD) is conducted. ${ }^{24}$ This is done to find understanding abou the phenomena studied from the subjects's view comprehensively, i.e. students.

Some scholars conducted the same study such as Saidurrahman on "Fiqh Jihad dan Terorisme: Perspektif Tokoh Ormas Islam Sumatera Utara". ${ }^{25}$ He concludes that there are many scholars and experts in Islamic law condemning the suicide bombings in Indonesia because they are barbaric which are actually not supported by the true understanding in jihad. However, most of them understand that the reasons behind the actions. The reasons are related to discrimination and unfair treatment to the Muslims in the world so that some Muslims then solve this discrimination with violence.

M. Zainuddin, in his study, proposes the anti-terrorism education. He concludes that: First, religious education should be able to shape the student character. Religion is an inner need for establishing a harmonious, peaceful, society. Re-orientation to religious education based on the universal and peaceful concept (rahmatan li al-'alamin) should be done. Second, the quality of Muslims should be improved, especially education producing the

${ }^{23}$ Survey done among 800 students at UIN, UIR, UMRI, UR, and Unilak. The criteria of students are: (1) third semester students and above; (2) students who are active intracurricular and extra-curricular organizations.

${ }^{24}$ Focused Group Discussion (FGD) is data collection technique generally done for qualitative study. The goal is to find the meaning from a theme according to group understanding. This technique is used to reveal the understanding and voice of the group based on the result of discussion focusing on the research problem. Burhan Bungin, Analisis Data Penelitian Kualitatif (Jakarta: RajawaliGrafindo Persada, 2003), 132.

${ }^{25}$ Saidurrahman, "Fiqh Jihad dan Terorisme: Perspektif Tokoh Ormas Islam Sumatera Utara”, Asy-Syir'ah: Jurnal Ilmu Syari'ah dan Hukum 46, No. 1 (2012). 
akhlaq al-karimah. The indicators are honesty, tolerant, and love toward other people. This reorientation should be implemented starting from Kindergarden level to Higher Education by reviewing the existing curriculum. ${ }^{26}$

Novan Ardy Wiyani also proposes the concept of Islamic education based on anti-terorism education. According to him, antiterrorism integrated into Islamic education includes citizenship, compassion, courtesy, fairness, moderation, respect for other, respect for the creator, self control, and tolerance. These should be integrated into the object of learning, learning content, learning experience and learning evaluation. ${ }^{27}$

Darmawati H. and Abdullah Thalib using qualitative method describes the response of Madrasah Aliyah (Islamic Senior High School) students on religious radicalism. His study is based on cognitive, affective, and conative aspect. Based on cognitive aspect, most of respondents know the existence of radical groups in Islam both in Indonesia and other countries. The respondents who have moderate view get the information from social and mass media. Based on affective perspective, the respondents are radical toward the ideology of other religions but they are moderate to concept of Islam and state as well as Islamic perspective on undertanding jihad. Based on conative perspective, the respondents are also moderate. ${ }^{28}$

As a result, this study will elaborate in-depth about radicalism among students in Riau. This is based on the symptom of returning to Islamic teachings among students. ${ }^{29}$ This can be seen from

\footnotetext{
${ }^{26}$ M. Zainuddin, “Pendidikan Antiterorisme”, Jawa Pos, April 14, 2010.

${ }^{27}$ Novan Ardy Wiyani, "Pendidikan Agama Islam Berbasis Anti Terorisme di SMA", Jurnal Pendidikan Islam 2, No. 1 (2013).

${ }^{28}$ Darmawati H. and Abdullah Thalib, "Respon Siswa Madrasah (MAN) terhadap Radikalisme Agama di Makassar", Jurnal Sulesana 10, No. 1 (2016).

${ }^{29}$ The interesting study shows that the potential of radical groups growth is usually in the science faculty. In the 1980, there is the growth of religious activities in several secular-based campuses such as Universitas Gadjah Mada (UGM), Universitas Indonesia (UI), Universitas Airlangga, Universitas Hasanuddin. These campuses are potent to be the place of radical groups, not Islamic-based campuses. See, the statement from Syarifuddin Jurdi in the seminr titled "Radikalisme Kawan Kita", http://uin-suka.ac.id/id/berita/detail/398/ page/fakultas, accessed March 27, 2017. After the changes from Institut Agama Islam Negeri (IAIN) to Universitas Islam Negeri (UIN), science study programs are established in
} 
the process of Student President Election at Universitas Islam Negeri (UIN, State Islamic University) Sultan Syarif Kasim Riau in 2018 in which all candidates promote the concept of khilafah and implementation of Islamic law. This can assumed that there is a strong tendency among students to have radicalism ideology. The flag of "La ilaha illa Allah" during the opening ceremony of Kemah Bakti Nasional Pramuka, followed with the takbir, supports this assumption. The second reason that there are some violent incidents toward minority groups, intolerance, terrorism and the rise of special groups promoting the ideology of Negara Islam Indonesia (NII, Islamic State of Indonesia). These can potentially threaten for the future of the state, mainly Indonesian students. ${ }^{30}$

As a result, this research is based on three indicators. First, namely student response in fighting the khilafah and Islamis law. Second, student response on differences. Third, student response on suicide bombings as the form of jihad.

\section{B. Discussion}

\section{Radicalism Conception}

From language perspective, radicalism is much different from terrorism. Radicalism is a process which aims to achieve the goal positively. Terrorism however is closely related to actions frightening other people. Therefore, terror is always done negatively. In line with the dynamics of pattern of social groups in a society, radicalism and terrorism have been understood in the same meaning. Radicalism is an embryo of terror action. If one has a radical thought, he may potentially produce terror actions. ${ }^{31}$

UIN. Students at science faculty of UIN Jakarta are prone to the radicalism. A study done by CSRC UIN Syarif Hidayatullah Jakarta indicates that the potential of radicalism among these students is about 22,2\%. This is quoted by Susanto, "Bahan Belajar Mandiri Sebagai Suatu Model Modul Studi Islam Berwawasan Deradikalisasi Pemahaman Agama”, Perspektif: Jurnal Ilmu Pendidikan 30, No. 2 (2016).

${ }^{30}$ A. Ghafur, Jejak Radikalisme Pemahaman Agama di Perguruan Tinggi (Ciputat: Cendekia Press, 2014), 1.

${ }^{31}$ M. Saekan Muchith, "Radikalisme dalam Dunia Pendidikan", ADDIN 10, No. 1 (2016), 171. 
Radicalism comes from the word "radical" which means "a root". ${ }^{2}$ Radicalism then means the radical ideology. It is an ideology which is intended to make changes or social and political changes with violence. This also means that radicalism is closely related to violent actions or conservative ideology which uses violence to disseminate their ideology. ${ }^{33}$

According to Yusuf al-Qaradhawi, the term of radical can be understood from two perspectives, left and right radical. ${ }^{34}$ In his view, it can be positive meaning but now its meaning has shifted. Muhamad then interprets radical Islam as the ideology in Islam aspiring for the implementation of Islamic law in social and political life and to achieve this goal violent actions are conducted. These violent actions sometimes are considered as jihad. $^{35}$

Jamhari and Jahroni refer radical Islam to a group having a high and fanatical ideology fighting for the change of existing system and value order. ${ }^{36}$ Abdurrahman Mas'ud refers a radicalims group as having the following characteristics:

a. Fighting for the implementation comprehensive Islamic law, Islamic law as the foundation of the state;

b. Referring to the past religious practice (salafi);

c. Regarding the West as enemy, especially its secularism and modernism ideology;

d. Opposing to liberal Islam in Indonesia. ${ }^{37}$

${ }^{32}$ John M. Echol and Hassan Shadily, Kamus Inggris-Indonesia (Jakarta: Gramedia, 2015).

${ }^{33}$ Departemen Pendidikan Nasional, Kamus Besar Bahasa Indonesia (Jakarta: Balai Pustaka, 2002), 919.

${ }^{34}$ Yusuf al-Qaradhawi, Islam Radikal, transl. Murtadho (Pajang Laweyan: Era Adicitra Intermedia, 2009), 35.

${ }^{35}$ Suprihatiningsih, "Spiritualitas Gerakan Radikalisme”, Jurnal Ilmu Dakwah 10, No. 2 (2012), 372.

${ }^{36}$ Jajang Jahroni and Jamhari, Gerakan Salafi Radikal di Indonesia (Jakarta: Rajawali Press, 2004), 2-3.

${ }^{37}$ Darmawati H. and Abdullah Thalib, "Respon Siswa Madrasah Aliyah Negeri (MAN) terhadap Radikalisme Agama di Makassar", Jurnal Sulesana 10, No. 1 (2016). 
In Badan Nasional Penanggulangan Terorisme (BNPT, National Counter Terrorism Agency) module, the indication of the radicalism and terrorism can be seen as from the following indicators: the obedience of being citizen, loyalty to Pancasila, the desire of establishing Islamic state, the support of Islamic law implementation, and violent actions as the form of Jihad. ${ }^{38}$

According to Yusuf al-Qardhawi, radicalism can be seen from the following indicators. First, fanaticm to an opinion without acknowledging to other opinions. Second, asking other peope to conduct Islamic teachings obliged by God. Third, hard actions which do not suit with the condition. Fourth, having bad feeling with others. Fifth, radicalism gets its peak when one claims that another man is infidel. ${ }^{39}$

Radicalism at least could be divided into two levels, though and action thought. In religious field, religious radicalism is reflected from destructive actions in the name of the dakwah within the same religion (internal) and other different religions (external). It also includes activities to force religious opinions, desires and aspirations with violence. Religious radicalism can be owned by any religion adherents including Muslims.

\section{Religious Understanding Pattern}

The interaction and symbolic theory mentions that the process of self is affected by social interaction done by someone. Douglas in Ardianto mentions that the consciousness about meaning comes from the interaction, a way to shape meaning, making cooperation with the other individuals through interaction. ${ }^{40}$

This concept produces the theory of the definition of the situation proposed by William Isac Thomas (1968) in

${ }^{38}$ Panji Futuh Rahman, "Penerapan Materi Deradikalisasi untuk Menanggulangi Radikalisme pada Ekstrakurikuler Keagamaan di di SMA Negeri 5 Bandung", Tarbawy 3, No. 2 (2016).

${ }^{39}$ Yusuf al-Qaradhawi, Islam Radikal, 40-55.

${ }^{40}$ Ardianto and Bambang Q-Anees, Filsafat Ilmu Komunikasi (Bandung: Simbiosa Rekatama Media, 2007), 136. 
Hendariningrum..$^{41}$ This concept states that human interaction is response to stimulus directly. This concept states that each individual respond the stimulus but his behavior is started with a stage of certain consideration in which the stimulus does not accept it without consideration at all. In this case the selective or interpretation process is conducted so that an individual gives a meaning to the stimulus accepted.

Based on the psychological perspective, an individual's behavior is affected by two factors, namely internal factor (temperament) and external factor (environment). The environmental factor includes the figures or leaders who are suitable with himself or herself. However, an individual who become an ideal figure will try to direct other people's behavior to reach the goal. ${ }^{42}$ This means that a figure plays a crucial function as the pioneer in deciding the structure, condition, ideology, and his group activities.

Based on this, there are some options selected by students as the central figure for them. Based on the survey, most of students refer to Habib Rizieq Shihab as their central figure.

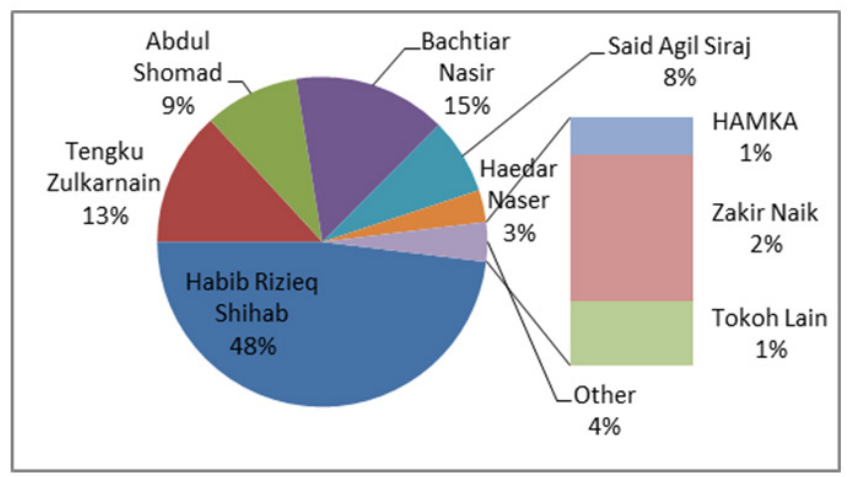

Figure 1

Some Options Selected by Students as the Central Figure for Them

\footnotetext{
${ }^{41}$ Nina Siti Salmaniah Siregar, "Kajian Tentang Interaksionisme Simbolik", Jurnal Perspektif 4, No. 2 (2011).

${ }^{42}$ Franklin S. Haiman, Leadership and Democratic Action (Houghton: Mifflin Company, 1971), 228.
} 
When one refers to the above symbolic-interaction theory, one will see that there is strong correlation between religious ideology owned by the figure with the students' religious ideology. As known, Habib Rizieq Shihab is the central figure who has a strong belief that "kepemimpinan kafir atas umat Islam adalah haram, walau dibolehkan konstitusi, karena Al-Qur'an dan as-Sunnah mengharamkannya" ("kafir leadership over Muslims is haram, even though the constitution allows it, because AlQur'an and Sunnah forbid it"). ${ }^{43}$

The dakwah thought of Habib Rizieq Shihab emphasizes on amar ma'ruf nahi munkar implemented strictly and firmly. This is based on Al-Qur'an dan as-Sunnah so that people have obligation in implementing the amar ma'ruf nahi munkar which becomes the crucial element of the implementation of Islamic law. ${ }^{44}$

Some reasons proposed by respondents why they select Habib Rizieq Shihab are as follows: (a) his consistency in defending Islam can be seen from the case of blasphemy suspected to ex-governor Jakarta, Basuki Tjahaja Purnama; ${ }^{45}$ (b) efforts done by Habib Rizieq Shihab in preaching the amar ma'ruf nahi munkar; (c) as the implementation of their concern on the decision of Habib Rizieq Shihab as the suspect, they regard that he is a victim of the ulama criminalization.

\footnotetext{
${ }^{43}$ Muhammad Rizieq Syihab, “Mukmin Sejati”, http://fpi.or.id/157-MukminSejati. html, accessed November 29, 2017.

${ }^{44}$ Farwah Quraisyiah, "Pemikiran Da'wah Habib Muhammad Rizieq Husein Syihab" Undergraduate Thesis, Universitas Islam Negeri (UIN) Syarif Hidayatullah Jakarta, 2017.

${ }^{45}$ The local election of DKI Jakarta 2017 was paid much attention from Indonesian people both in Jakarta and outside Jakarta. Since the registration of three candidates, AhokJarot, Anis-Sandiaga, and Agus-Sylvia on September 20, 2016, information about these candidates was discussed on online media by the haters of these candidates. They even use religious emotion bot Islam and other religions. A study about the hate speech related to the election of Jakarta Governor can be seen from Christiany Juditha's article, "Hatespeech di Media Online: Kasus Pilkada DKI Jakarta 2017", Aplikasi Informatika dan Informasi Komunikasi Publik Kementerian Komunikasi dan Informatika RI, 2017.
} 


\section{The Potential of Radicalism}

The term of "potentiality" has the meaning of hidden talent or potentiality to conduct actions in the certain attitude in future. ${ }^{46}$ In Kamus Besar Bahasa Indonesia (KBBI, Big Dictionary of Indonesia), the "potential" is the ability having possibility to develop. The meaning of potentiality in this research is a hidden thing and it is very possible to develop or acting in certain time. The potential is a radicalism attitude among students in Pekanbaru. To read such potential, three indicators are used, namely students response on differences, the jihad conception, and the establishment of khilafah or implementation of Islamic law.

First, the attitude to differences. This research shows that basically students are positive to the differences. $67 \%$ respondents accept, agree, and like to see the differences and the rest are 33\% who reject, dislike, and disagree with differences. The further detail of the students' response on differences is as follows:

a. Students attitude to the informants or preachers who have different religious understanding with the students is that $59 \%$ students are happy, sympathy, and friendly. But, $41 \%$ students regard that it is disturbing, not sympathy, and they are suspicious to them;

b. The students' attitude of receiving people having the different ideology to be candidates of campus organization leaders is that $50 \%$ students accept and respect to them while the rest are worry and it can be a threat for students;

c. The students' response on preachers who invite the audiences to follow their ideology which is different with their ideology is that $74 \%$ students are unhappy while $26 \%$ are happy, emphatic;

d. The students' response on people or group who have different opinion with them is that $79 \%$ of them

${ }^{46}$ M. Hafi Anshari, Kamus Psikologi (Surabaya: Usaha Nasional, 1996), 482. 
accept, respect to this. But, $21 \%$ students reject, disrespect to this;

e. The students' response on the people who have integrity, honesty, brave, firm in the public positions but have different ideology with them is that $63 \%$ students accept and respect to them but $37 \%$ of them reject and disrespect to them.

Second, the support of Khilafah Islam and implementation of Islamic law. There is an opinion from students that Islam is a complete and comprehensive religion (kaffah). It means that Islam regulates all aspects of human life. It provides life guidance for all human beings. It is not only a concept but it also as the moral keeper (akhirat), but also it has a larger context covering the temporary world matters. This supports students to use the khilafah and Islamic law as the crucial instrument to solve the problems of state, politics and social in the contemporary Indonesia.

The khilafah system is always believed by its followers as the best solution for the social diseases of Muslim society. It is able to solve all problems in the Muslim society. In Indonesian context, khilafah is not only about the replacement of corruptive politicians. Therefore, some people regard that the transformational changes should be done by upholding the Islamic leadership in the form of the khilafah.

The following figure is the description of students' response on the solution to the problems of Muslim society and Indonesia. 


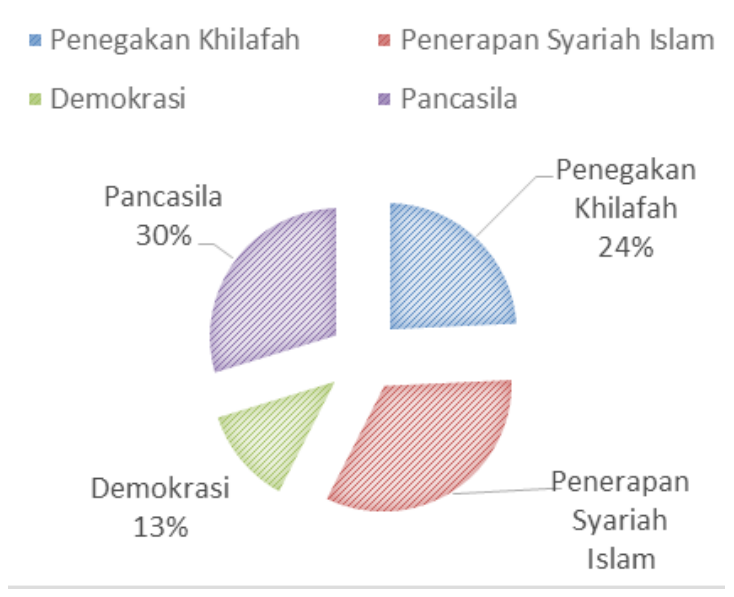

Figure 2

The Description of Students' Response on the Solution to the Problems of Muslim Society and Indonesia

Arguments proposed by those who want to implement Islamic law and establish the khilafah is based on the formalization of Islamic law or making Islamic law as the jurisprudential foundation of daily life. The basis that they use is the Islamic law as the legal reasoning. It is obligation for all Muslims to realize it in the real life. In other words, Islam should provide the clear corridor to live. Islam has ideal values and ways starting from the bath room to the mosque, from happiness to sadness and from hablun min an-nas (human relations) to hablun min Allah (relationship with God).

In this context, students may not differentiate between Islamic law and fiqh, between doctrine and civilization, or between normativity and history of religion. The real problem is that when the implementation of Islamic law is done through the formulation of Islamic law to be fiqh. In fact, fiqh is the product of human thought, the result of the ulama's ijtihad on the syari'ah. By shifting the Undang-undang Dasar 1945 (UUD, Constitution of Indonesia Republic), particularly the section 29 verse 1 on "the state is based on the one God' to the state based on Islamic 
law negates people and groups who have not known about the Islamic law concept". In the context of the khilafah support, $24 \%$ Muslim students in are waiting for the implementation of Khilafah Islamiyah. It is a hope to re-implement the Islamic government as the prophet and his companion era. This is based on the successful achievement reached at that time. The success of Islam in the Abbasiyah Dynasty through the spread of Islam and the development of Islamic civilization has become the reflection which should be re-emerged. Abbasiyah is a glory period of Muslim society in which the development of all disciplines like philosophy, law, technology, and others were growing significantly. ${ }^{47}$

Third, the jihad by killing? In this study, they are asked about their response on someone or a student who kill other people in the name of jihad. Their response can be seen as follows:

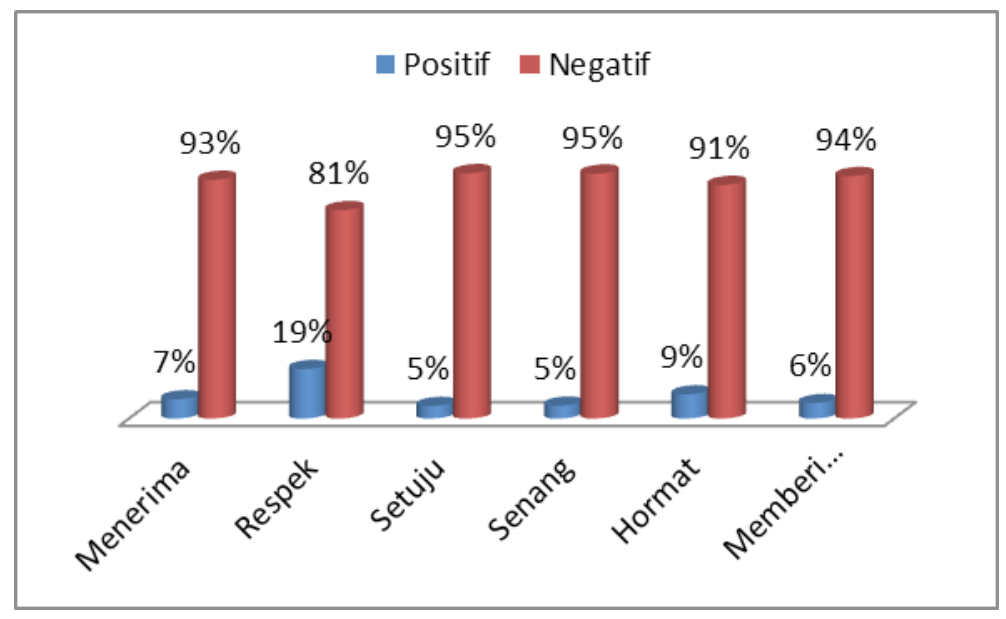

Figure 3

Response on Someone or a Student who Kill Other People in the Name of Jihad

${ }^{47}$ Idil Akbar, "Khilafah Islamiyah: antara Konsep dan Realitas Kenegaraan (Republik Islam Iran dan Kerajaan Islam Arab Saudi)", Journal of Government and Civil Society 1, No. 1 (2017). 
The above data shows that most respondents disagree with the action, namely reject (93\%), disrespect (81\%), disagree (95\%), dislike (95\%), disregard (91\%), and not support (94\%). However, the data also shows that some of them accept (7\%), respect (19\%), agree (5\%), happy (5\%), favor (9\%) even they support (6\%). This means that $7 \%$ students accept to the action, $19 \%$ respect to the action and 5\% students agree and they are happy with the jihad by killing other people who have different religion or ideology.

The similar view is also found from a leader of the central Hizbut Tahrir Indonesia (HTI) stating that jihad according to Islamic law is a fight in a war but not all wars are identical with, like a war with bughat and a fight with brothers is not jihad. Although killing is not a part of jihad, but coming to pick the death by directly fighting with the enemy is istisyhad which is supported and legalized. He also mentions that jihad should have benefits for Muslims. This at least frighten to the infidels so that they are afraid of the strength of Muslim society. In this case, the dakwah and the glory of Muslim society should be prioritized. ${ }^{48}$

Arguments proposed by students who agree with the action is that: First, normative reason namely jihad. ${ }^{49}$ Second, Islam is the only true religion so that fighting for it is a must for Muslims. ${ }^{50}$ Third, Islam nowadays has become a discriminated by politicians both in national and international level. This becomes their reason to conduct the jihad.

${ }^{48}$ For further detail, see Saidurrahman, "Fiqh Jihad dan Terorisme: Perspektif Tokoh Ormas Islam Sumatera Utara”, Jurnal asy-Syir'ah: Jurnal Ilmu Syari'ah dan Hukum 46, No. 1 (2012).

${ }^{49}$ The concept of jihad should be reconstructed so that religion is not used as licenceto kill (a permit letter to kill) for others due to religious or belief differences. Islam in fact declares itself as a religion of rahmatan li al-'alamin (Q.S. al-Anbiya' [21]: 107) and it also guarantees the freedom of religion and belief (Q.S. al-Baqarah [2]: 256). Abdul Mustaqim, "Konflik Teologis dan Kekerasan Agama dalam Kacamata Tafsir", Epistemé: Jurnal Pengembangan Ilmu Keislaman 9, No. 1 (2014).

${ }^{50}$ This is perhaps still debatable because it is too extreme in practicing religion. The extreme radical ideology (al-ghuluw wa at-tatharruf) supports someone to act violently. He is intolerant and anti-peace for others who have different theology. Yusuf al-Qaradhawi, Zhahirah al-Ghuluw fi at-Tafkir (Kairo: Maktabah Wahbah, 1990), 3-4. 


\section{Conclusion}

This study shows that: First, the students' response on differences is very positive. However, there are some cases which are responded negatively such as preaching to follow the practice of different ideology. Second, related to the establishment of the caliphate and implementation of Islamic law, most students support it. Some of them however support democracy and the Pancasila values as the foundation of Muslim life in Indonesia. Third, related to issue of jihad, most students disagree with the concept of jihad by killing. However, minority of them agree with the jihad by killing. 


\section{REFERENCES}

Adjie S. Terorisme. Jakarta: Surya Multi Grafika, 2005.

Akbar, Idil. "Khilafah Islamiyah: antara Konsep dan Realitas Kenegaraan (Republik Islam Iran dan Kerajaan Islam Arab Saudi)", Journal of Government and Civil Society 1, No. 1 (2017).

Algar, Hamid. Wahabisme: Sebuah Tinjauan Kritis. Jakarta: Paramadina, 2008.

Anshari, M. Hafi. Kamus Psikologi. Surabaya: Usaha Nasional, 1996.

Ardianto and Bambang Q-Anees. Filsafat Ilmu Komunikasi. Bandung: Simbiosa Rekatama Media, 2007.

Asfar, Muhammad (ed.). Islam Lunak Islam Radikal: Pesantren, Terorisme, dan Bom Bali. Surabaya: JP Pres, 2003.

Bakti, A.S. "Terorisme dan Tantangan Radikalisme Baru dalam Sistem Kepemimpinan Nasional", Jurnal Politik dan Keamanan Nasional 5, No. 1 (2015).

Bungin, Burhan. Analisis Data Penelitian Kualitatif. Jakarta: RajawaliGrafindo Persada, 2003.

Darmawati H. and Abdullah Thalib, "Respon Siswa Madrasah Aliyah Negeri (MAN) terhadap Radikalisme Agama di Makassar", Jurnal Sulesana 10, No. 1 (2016).

Departemen Pendidikan Nasional. Kamus Besar Bahasa Indonesia. Jakarta: Balai Pustaka, 2002.

Echol, John M. and Hassan Shadily. Kamus Inggris-Indonesia. Jakarta: Gramedia, 2015.

Ghafur, A. Jejak Radikalisme Pemahaman Agama di Perguruan Tinggi. Ciputat: Cendekia Press, 2014.

Haiman, Franklin S. Leadership and Democratic Action. Houghton: Mifflin Company, 1971.

Hanafi, Imam. "Foucault dan Pendidikan Kita", Riau Pos, June 7, 2017. . "Orientasi Fiqhiyah dalam Pendidikan Islam", Proceding Annual International Conference of Islamic Studies (AICIS) 2014. Jakarta: Kementerian Agama RI, 2014. 
Haryono, Yudhie. Melawan dengan Teks. Yogyakarta: Resist Book, 2005.

Jahroni, Jajang and Jamhari. Gerakan Salafi Radikal di Indonesia. Jakarta: Rajawali Press, 2004.

Juditha, Christiany. "Hatespeech di Media Online: Kasus Pilkada DKI Jakarta 2017", Aplikasi Informatika dan Informasi Komunikasi Publik Kementerian Komunikasi dan Informatika RI, 2017.

Jurdi, Syarifuddin. "Radikalisme Kawan Kita", http://uin-suka. ac.id/id/berita/detail/398/page/fakultas, accessed March 27, 2017.

Lauba, J.H. Psychological Study of Religion. New York: MacMillan, 1912.

Muchith, M. Saekan. "Radikalisme dalam Dunia Pendidikan", ADDIN 10, No. 1 (2016).

Muhammad, Ali. Agama dan Konflik Sosial. Bandung: Marja, 2013.

Munip, Abdul. "Mencegah Radikalisme Agama di Sekolah", Jurnal Pendidikan Islam 1, No. 2 (2012).

Mustaqim, Abdul. "Konflik Teologis dan Kekerasan Agama dalam Kacamata Tafsir", Epistemé: Jurnal Pengembangan Ilmu Keislaman 9, No. 1 (2014).

Prasetyo, Andry. "Enam Terduga Teroris dari Satu Sekolah", https://m.tempo.co/ read/news/2011/01/27/063309390/ enam-terduga-teroris-klaten-dari-satu-sekolah, accessed March 10, 2017.

al-Qaradhawi, Yusuf. Islam Radikal, transl. Murtadho. Pajang Laweyan: Era Adicitra Intermedia, 2009.

. Zhahirah al-Ghuluw fi at-Tafkir. Kairo: Maktabah Wahbah, 1990.

Quraisyiah, Farwah. "Pemikiran Da'wah Habib Muhammad Rizieq Husein Syihab" Undergraduate Thesis, Universitas Islam Negeri (UIN) Syarif Hidayatullah Jakarta, 2017.

Rahman, Panji Futuh. "Penerapan Materi Deradikalisasi untuk Menanggulangi Radikalisme pada Ekstrakurikuler Keagamaan di di SMA Negeri 5 Bandung", Tarbawy 3, No. 2 (2016). 
Saidurrahman. "Fiqh Jihad dan Terorisme: Perspektif Tokoh Ormas Islam Sumatera Utara”, Asy-Syir'ah: Jurnal Ilmu Syari'ah dan Hukum 46, No. 1 (2012).

Shihabuddin, A. Membongkar Kejumudan. Bandung: Mizan, 2013.

Siregar, Nina Siti Salmaniah. "Kajian Tentang Interaksionisme Simbolik", Jurnal Perspektif 4, No. 2 (2011).

Suprihatiningsih. "Spiritualitas Gerakan Radikalisme", Jurnal Ilmu Dakwah 10, No. 2 (2012).

Susanto. "Bahan Belajar Mandiri Sebagai Suatu Model Modul Studi Islam Berwawasan Deradikalisasi Pemahaman Agama", Perspektif: Jurnal Ilmu Pendidikan 30, No. 2 (2016).

Syihab, Muhammad Rizieq. "Mukmin Sejati”, http://fpi.or.id/157MukminSejati.html, accessed November 29, 2017.

Wahid, Abdul. "Tendensi Antipluralisme dalam Pendidikan Islam: Kritik Teks Buku Ajar PAI SMU/SMK”, Ulumuna 12, No. 2 (2003).

Witdarmono, “Teror dalam 'Benak' Agama: Wacana Agama dalam Radikalisme”, Kompas, December 30, 2002.

Wiyani, Novan Ardy. "Pendidikan Agama Islam Berbasis Anti Terorisme di SMA", Jurnal Pendidikan Islam 2, No. 1 (2013).

Zainuddin, M. “Pendidikan Antiterorisme”, Jawa Pos, April 14, 2010. 
